\title{
Using epidemiology to study adverse outcomes in anaesthesia
}

What is epidemiology? Why do anaesthetists need epidemiological methods? In this presentation, these questions will be addressed using relevant examples to illustrate the main issues.

\section{What is epidemiology?}

While the term "epidemiology" makes one think of epidemics, epidemiology actually covers a range of activities from drug trials to surveys of patient satisfaction. Unlike many other specialities, the common basis of epidemiology is methodology rather than content per se.

Epidemiology has two main features. First, the unit of observation is usually groups of people rather than individuals or cells, molecules or animals. Secondly, epidemiology is concerned with making comparisons of one group with another. Ideally a group with a characteristic of interest is compared with a group of persons who are similar except for the characteristic of interest. Since this is rarely feasible, several methods are available to help researchers correct for the differences between the two groups. Clinical epidemiology is basically the application of epidemiological principles and methods to problems encountered in clinical medicine.

\section{Basic principles of epidemiology}

The basic purpose of clinical epidemiology is to develop and apply rigorous methodology to clinical observations that will lead to valid clinical conclusions. The basic principles of epidemiology are as follows:

\section{A Population versus a sample}

In an ideal world, we would study all persons who undergo a common experience, or are exposed to a particular factor or who have a specific disease. However, practically, we can only study a subset of a population; we call this subset a "sample."

In order to be able to apply the results of investigations to the population (i.e., all persons who have an anaesthetic), the sample chosen must be representative of all persons undergoing anaesthesia. The best way to ensure that the sample is truly representative is to use a "probability" sample, also known as a random sample. This means that all persons in the population have an equal chance of being chosen.
B Three factors to consider in epidemiological research are I. Bias; 2. Chance; 3. Validity

1 Bias (systematic error): may be defined as any difference between the true value and that actually obtained due to all causes other than sampling variability.

2 Chance (random error): Because of random variation, the characteristics of persons in a particular sample are different from others in the population from which it was taken (that is sampling variability).

3 Validity. The ability of the study to determine the "truth."

- Internal validity: Conditions within the design of the study are such that the results achieved are free from contamination and unlikely due only to chance.

- External validity: Are the results of the study applicable to other situations? This is known as generalizability of the study results. Internal and external validity are a paradox. If internal validity is high, then usually generalizability is low. This is because conditions of the study are so strict that the results only apply to populations identical to those under study. This is a common concern of the randomized clinical trial (RCT). Typically such studies are performed at teaching hospitals, under idealized conditions, with academic specialist physicians as the principal investigators. While the results are usually important, this does not mean that the outcomes found will be appropriate to other populations at, say, community hospitals.

\section{Efficacy, effectiveness and efficiency}

Efficacy studies try to show that a new intervention works in an ideal setting. These studies are typically a RCT in major teaching hospitals, with strict inclusion/exclusion criteria, a large staff of research assistants to ensure patient compliance and methods to ensure adequate follow-up of patients.

Effectiveness studies try to show how an intervention works in the real world. What are the outcomes of, for example, the administration of an anaesthetic in a small remote hospital?

Department of Community Health Sciences and Anesthesia, University of Manitoba, Winnipeg MB, R3E OW3. 
TABLE I* Questions which epidemiology can help to answer

\begin{tabular}{|c|c|}
\hline & Anaesthesia example \\
\hline NORMALITY/ABNORMALITY: Is a person sick or well? & What is the normal course for persons receiving anaesthestic services? \\
\hline $\begin{array}{l}\text { DIAGNOSIS: How accurate are diagnostic tests or strategies used to detect } \\
\text { a disease? }\end{array}$ & $\begin{array}{l}\text { How well can you predict which patients will have malignant hyper- } \\
\text { thermia and which will not? }\end{array}$ \\
\hline $\begin{array}{l}\text { FREQUENCY: How often does a disease occur? What are the changes } \\
\text { over time? }\end{array}$ & What is the rate of postoperative MI? over time? \\
\hline RISK: What factors are associated with an increased likelihood of disease? & Can we predict which patients are high risk for adverse events? \\
\hline PROGNOSIS: What are the consequences of having a disease? & $\begin{array}{l}\text { What is the longterm outcome for patients with postoperative } \\
\text { neurological deficits? }\end{array}$ \\
\hline TREATMENT: How does treatment change the future course of a disease? & Will the use of pulse oximeters eliminate hypoxic events? \\
\hline Should you replace an old treatment with a new one? & Should you use isoflurane rather than halothane? \\
\hline $\begin{array}{l}\text { PREVENTION: Does intervention in people without disease keep disease } \\
\text { from arising }\end{array}$ & Should all patients receive antiemetics? \\
\hline Does early detection and treatment alter the course of a disease? & Will it make a difference? Will it be harmful to some patients? \\
\hline CAUSATION: What conditions result in disease? & Does halothane "cause" postoperative liver necrosis? \\
\hline
\end{tabular}

*Modified from Fletcher, Fletcher \& Wagner. Clinical Epidemiology: the essentials.

Efficiency studies aim to show what is the most efficient intervention in terms of cost, personnel, compliance and the like given more than one alternative. Such studies must consider outcomes of care as well as inputs to that care.

While we have many examples of efficacy studies, there are a paucity of effectiveness and efficiency studies in medicine in general and in anaesthesia in particular.

\section{Research designs in epidemiology}

\section{Experimental.}

In experimental studies the intervention is under control of the investigator. Chances are minimized that factors outside control of the investigator may have affected the results. Examples include toxicology or other animal studies and in humans, the randomized controlled trial.

\section{Observational}

The intervention is not under control of the investigator. For example, persons are not randomly allocated to smoke or not to smoke, but select themselves to some degree. We then "observe" which persons get lung cancer (smokers or non-smokers).

When considering causation - does factor $x$ cause disease $y$ ? -one observational study should not be used in isolation. Results from experimental studies are always more powerful (and convincing) than information from observational studies. However, by considering the results from a number of observational studies - each with somewhat differing methodologies, from various centres in the world, we can come to a consensus on the degree of the relationship between factor $x$ and disease $y$.
Observational studies are particularly useful in certain circumstances. These include situations where it would be unethical or impractical to perform a RCT. As well, it may be difficult to perform a RCT because they are usually very expensive and may present difficulties for an investigator to obtain funding. Therefore, you may only get the information you need from an observational study.

A third reason for the usefulness of the observational approach is for the study of rare events. If the condition is uncommonly rare, thousands of subjects would be needed in both arms of a randomized controlled trial.

Observational studies can further be divided into two major groups - descriptive or analytical. Descriptive studies are essentially hypothesis-generating. However, observational analytical studies can be used to test an hypothesis.

\section{Timing of data gathering}

There is much misuse of the terms prospective and retrospective. Some authors define retrospective as any study which uses information collected before "now." This is too restrictive a definition. The term prospective means that information about the patient relevant to the outcome (such as age, sex, physical status, exposure to drug) is collected before the outcome is known. Retrospective implies the reverse. The outcome is known before information on risk factors is collected.

\section{Comparison or control groups}

As mentioned earlier, epidemiology is concerned with comparing one group of persons with a factor of interest with another group of persons who are similar but do not have the factor of interest. There are two main types of 


\begin{tabular}{|c|c|}
\hline & Anaesthesia example \\
\hline $\begin{array}{l}\text { DEATH: A universal health outcome, the timeliness of the event being } \\
\text { the issue. }\end{array}$ & $\begin{array}{l}\text { What is the rate of perioperative mortality associated with anaesthesia } \\
\text { (as opposed to surgery)? }\end{array}$ \\
\hline $\begin{array}{l}\text { DISEASE: A combination of symptoms, physical signs and laboratory } \\
\text { test results. }\end{array}$ & What is the morbidity associated with anaesthesia? \\
\hline $\begin{array}{l}\text { DISABILITY: The funclional status of patients in terms of ability to live } \\
\text { independently or go about their daily lives at home, work or recreation. }\end{array}$ & For outpatients, does the choice of anaesthetic delay return to work? \\
\hline $\begin{array}{l}\text { DIsCOMFORT: Uncomfortable symptoms, such as pain, nausea, vertigo, } \\
\text { tinnitus or fatique. }\end{array}$ & What the rates of postoperative $N \& V$, headache, backache etc.? \\
\hline $\begin{array}{l}\text { DISSATISFACTION: emotional or mental states, such as agitation, sadness } \\
\text { or anger. }\end{array}$ & Are the numbers of medical legal cases to anaesthetists increasing? \\
\hline DOLLARS: What is the financial impact of disease and its treatment? & Are the costs of new anaesthesia monitors justified? \\
\hline
\end{tabular}

*Modified from Fleıcher, Fletcher \& Wagner.

comparison groups - concurrent or historical. Generally the use of historical comparison groups are not recommended.

\section{Choosing controls}

One of the main biases to contend with in observational research is selection bias, that is, subjects in the sample are not representative of the population. A random sample could be used, say, of all patients undergoing anaesthesia. However, too often in the literature, the investigator has not picked a truly random sample, but uses those patients who are available to him or her. These cases are chosen at the "convenience" of the investigator and therefore this is known as a "convenience" sample. The assumptions being made in using a convenience sample are that the cases selected are representative of all patients with that disease and that the controls are representative of all persons without that disease. These assumptions are not always correct and result in biased results.

Who should the researcher use as controls? There are various strategies for choosing controls. The researcher could study a random sample of hospitalized patients who did not have the disease being studied and match them by five-year age group and residence to the cases. An even better way in some circumstances would be by casenomination. That is, the researcher asks the case or proxy to name a personal acquaintance of approximately the same age who may serve as a control. Since persons tend to associate with other persons of the same sociodemographic profile, the nominated control will be similar to the case. Additional factors such as diet and smoking history may also have to be determined by the researcher as these may affect the outcome being studied. Since choosing more representative controls is more expensive and energy-consuming, we can see why the researcher is too tempted to use a convenience sample.
Why should anaesthetists learn about epidemiology?

1 The specialty appears "stuck" in traditional methods, such as the use of case reports, case series, anecdotes, and one's "own experience." There are several other research designs which could be helpful in defining problems in clinical practice.

2 The results of laboratory (animal) findings cannot always be translated directly to humans (example dioxins, cigarettes). Critical evaluations must be done on humans to know definitively the effects of a substance or procedure, but a randomized controlled trial is not always feasible or ethical.

3 Due to financial concerns, cost containment and resource allocation questions, there is an increasing need to do scientific evaluations of the efficacy, effectiveness and efficiencies of new technologies and drugs. Again, controlled trials are not always feasible and alternative designs may provide some of the answers.

With the rise in consumerism among the public, there is a greater need to demonstrate that one's clinical approach is not only effective in overcoming the problem at hand, but that a particular method is the most cost-effective. Epidemiology can be helpful in carrying out these evaluations.

Some of the questions which epidemiology can help the anaesthetist to answer are seen in Table I. These include questions around diagnosis, frequency of a problem, risk, prognosis, treatment, prevention and causation.

In studying adverse outcomes in anaesthesia, observational methods have proved to be feasible, reliable and valid. The major types of outcomes studied in epidemiology and examples of these studies carried out in Manitoba are shown in Table II.

A current movement in outcomes research has been the increasing use of databases. Databases may be defined as 
a systematic gathering of data often for reasons other than for research. At the Health Sciences Centre in Winnipeg, the Department of Anesthesia has had a Follow-up Program since 1974 which recorded information about the patient, the anaesthetic technique and drugs used and untoward events occurring in the perioperative period. Data were collected by both anaesthetists and a dedicated anaesthesia follow-up nurse. Thus for each patient attended by an anesthetist there is a computerized record of that episode of care. It is likely that we will continue to see more hospitals and departments of anaesthesia acquiring databases.

\section{What are the advantages of databases?}

Databases are relatively easy to use and relatively inexpensive to develop and maintain. They can be used to answer a number of different questions rather than the usual "one" from an experimental approach. They can be used to give a "first look" at a particular problem letting us know if it is worthwhile to undertake a RCT. If it is unethical or unfeasible to perform a RCT, databases, with their large number of cases, can help to answer research questions. Databases can often be linked to other databases to add more information. Databases can be used for surveillance of untoward events, monitoring of resource allocation, administration and other purposes.

What are the disadvantages of databases? Databases are a form of observational study and may be subject to a number of biases. Database research, being observational, usually involves "hypothesis generating" rather than hypothesis testing. The database can only answer questions relating to the variables being collected. If new issues arise, these may not be included in the data collection. The information in a database may vary in its reliability and validity and those using them must be aware of their limitations.

It is a reality of practising in the clinical realm that patients are inconsiderate and do not behave as biochemical and physiological studies suggest that they should. It is much more difficult to determine what is the truth in clinical medicine and how to go about judging what is the truth. Some of the methods developed by epidemiologists can be useful to the practising clinician. Further bridges between the specialties of anaesthesia and epidemiology should be sought to the mutual benefit of both.

\section{Bibliography}

Fletcher RH, Fletcher SW, Wagner EH. Clinical Epidemiology: The essentials. Baltimore: Williams \& Wilkins, 1988.

Streiner DL, Norman GR, Monroe Blum H. PDQ Epidemiology. Burlington Ontario; B.C. Decker Inc., 1989. 


\section{L'utilisation de l'épidémiologie dans l'étude de la morbidité en anesthésie}

Qu'est-ce que l'épidémiologie? Pourquoi les anesthésistes ont-ils besoin des méthodes épidémiologiques? Dans cette presentation, nous examinerons ces questions en citant des exemples pertinents pour illustrer les points principaux.

\section{Qu'est-ce que l'épidémiologie?}

Même si l'on pense que le terme «épidémiologie » fait penser aux épidémies, l'épidémiologie en fait couvre un champ d'activités qui s'étend des essais des médicaments jusqu'aux enquêtes sur la satisfaction des patients. A la différence de beaucoup d'autres spécialités, le fondement de l'épidémiologie est la méthodologie plutôt que le contenu en soi.

L'épidémiologie a deux caractéristiques principales. La première : l'unité d'observation est habituellement un groupe de personnes plutôt que des individus ou des cellules, des molécules ou des animaux. Deuxièmement, l'épidémiologie se préoccupe de faire des comparaisons d'un groupe par rapport à un autre. Idéalement un groupe avec des caractéristiques intéressantes est comparé avec un groupe de personnes qui sont semblables sauf pour la caractéristique définie. Puisque ceci est rarement réalisable, plusieurs méthodes sont disponibles pour aider les chercheurs à ajuster les différences entre les deux groupes. L'épidémiologie clinique est au fond l'application des principes et des méthodes de l'épidémiologie aux problèmes rencontrés en médecine clinique.

\section{Principes fondamentaux de l'épidémiologie}

La fonction principale de l'épidémiologie clinique est de développer et d'appliquer une méthodologie rigoureuse aux observations cliniques ce qui permettra d'obtenir des conclusions cliniques valides. Les principes fondamentaux de l'épidémiologie sont les suivants:

\section{a) Population versus échantillon}

Dans un monde idéal, nous étudierions toutes les personnes qui partagent une expérience commune, ou sont exposées à un facteur particulier ou qui ont une maladie définie. Cependant de façon pratique nous n'examinons qu'un partie de cette population et appelons cette partic un échantillon.
Si nous voulons appliquer les résultats de nos évaluations à la population e.g. " toutes les personnes qui ont été anesthésiées ", l'échantillon choisi doit être représentatif de toutes les personnes qui ont eu une anesthésie. Le meilleur moyen de s'assurer que l'échantillon est vraiment représentatif est d'utiliser un échantillon «probabiliste", aussi connu comme échantillon aléatoire. Ceci signifie que toutes les personnes dans la population ont une chance égale d'être choisies.

b) Il y a trois facteurs à considérer dans la recherche épidémiologique: 1. Le biais, 2. La chance, 3. La validité 1 Le biais (erreur systématique) : peut être défini comme toute différence entre la valeur réelle et celle obtenue en fait pour toute cause autre que les fluctuations d'échantillonage.

2 La chance (erreur aléatoire): à cause des variations aléatoires, les caractéristiques d'une personne dans un échantillon donné sont différentes de celles d'autres personnes dans la population qui a servi de source pour l'échantillon (ceci est la variabilité d'échantillonnage).

3 La validité : il s'agit de la capacité de l'étude à déterminer « la vérité ".

- Validité interne : les conditions de l'étude sont telles que les résultats obtenus sont libres de contamination et peu susceptibles d'être dûs seulement à la chance.

- Validité externe : est-ce que les résultats de l'étude sont applicables à d'autres situations? Ceci est connu comme la généralisabilité des résultats de l'étude. Les validités interne et externe sont paradoxales. Si la validité interne est élevée, dès lors la généralisabilité habituellement est faible. Cette situation se produit parce que les conditions d'étude sont tellement strictes que les résultats s'appliquent seulement aux populations identiques à celle étudiée. Ceci est une préoccupation courante dans les études cliniques contrôlées. De façon typique, de telles études sont réalisées dans des hôpitaux d'enseignement, sous des conditions idéales, avec comme chercheurs principaux des médecins spécialistes académiciens. Mais si les résultats sont habituellement importants, ceci ne signifie pas qu'ils seront appropriés pour d'autres populations (hôpitaux communautaires). 
c) Efficacité, impact, et efficience (rendement)

Les études d'efficacité tendent à montrer qu'une nouvelle intervention fonctionne dans un environnement contrôlé. Ces études sont habituellement des études contrôlées qui se déroulent dans des hôpitaux d'enseignement, avec des critères stricts d'inclusion et d'exclusion, un personnel important d'assistants de recherche qui se préoccupent de la compliance des patients et enfin des méthodes qui permettent d'assurer un suivi adéquat des patients. Les études d'impact (réel) tendent à montrer comment une intervention fonctionne dans la réalité. Ainsi quels sont les résultats de l'administration d'un anesthésique dans un petit hôpital éloigné?

Les études d'efficience (rendement) tentent à montrer quelle intervention offre le meilleur rendement de coût, de personnel, de compliance et items semblables, lorsque l'on a plus d'une alternative. De telles études doivent considérer les résultats des soins aussi bien que les intrants (inputs) compris dans ces soins.

Bien que nous ayons de nombreux exemples d'études d'efficacité, il y a très peu d'études d'impact et d'efficience en médecine en général et en particulier en anesthésie.

\section{Modèle de recherche en épidémiologie}

\section{Expérimental}

Dans les études expérimentales l'intervention est sous le contrôle du chercheur. On y minimise les chances que des facteurs hors du contrôle du chercheur puissent influencer les résultats. On peut citer comme exemple les études de toxicologie ou autres études animales, et chez l'humain l'étude contrôlée randomisée.

\section{Étude d'observation}

L'intervention n'est pas sous le contrôle de l'évaluateur. Par exemple, les personnes ne sont pas assignées de façon aleátoire à fumer ou ne pas fumer, mais se choisissent elle-même à un certain degré. Nous observons ensuite quelles personnes développent un cancer du poumon (fumeur ou non fumeur).

Lorsque l'on s'intéresse à des relations cause-effet, une seule étude d'observation ne peut être considérée isolément. Les résultats tirés d'études expérimentales sont toujours plus puissants et convaincants que l'information tirée d'études d'observation. Cependant, lorsque l'on recueille les résultats d'un certain nombre d'études d'observation, chacune avec une méthodologie quelque peu différente et venant de nombreux centres dans le monde, nous pouvons atteindre un consensus sur le degré d'association entre le facteur $x$ et la maladie $y$.

Les études d'observation sont particulièrement utiles dans certaines circonstances. Celles-ci comprennent les situations où il serait non-éthique ou peut pratique de réaliser une étude contrôlée randomisée. De la même façon il pourrait être difficile de réaliser une étude contrôlée parce qu'elles sont habituellement très coûteuses et sont souvent difficiles à financer. Dès lors, on ne peut obtenir l'information désirée qu'à partir d'une étude d'observation.

Une troisième raison pour l'utilité de l'approche par observation est l'étude des événements à incidence rare. Si la situation cherchée est très rare, il peut y avoir nécessité d'enrôler des milliers de sujets dans chaque groupe d'une étude contrôlée randomisée.

Des études d'observation peuvent être subdivisées en deux groupes importants : descriptives ou analytiques. Les études descriptives sont essentiellement génératrices $\mathrm{d}$ 'hypothèses, alors que les études analytiques peuvent être utilisées pour vérifier des hypothèses.

\section{Échéancier de collecte des données}

Il y a beaucoup d'emploi inadéquat des termes prospectif et rétrospectif. Quelques auteurs définissent comme rétrospective toute étude où l'information est colligée avant le moment présent ; ceci est une définition trop restrictive. Le terme prospectif signifie que le recueil de l'information chez le patient à propos de l'item cible (tel que l'âge, le sexe, l'état physique, l'exposition à une substance) se fait avant que cet item cible (outcome) soit connu. Rétrospectif implique le contraire. L'item ou événement cible est connu avant que l'information sur les facteurs de risque ne soit recueillie.

\section{Groupe contrôle ou de comparaison}

Tel que mentionné plus tôt, l'épidémiologie se préoccupe de comparer un groupe de personnes porteuses d'une caractéristique donnée, avec un autres groupe de personnes semblables mais sans cette caractéristique. Il y a deux types principaux de groupes de comparaison: contemporain ou historique. Habituellement l'utilisation du groupe de comparaison historique n'est pas recommandée

\section{Le choix des contrôles}

Un des biais principaux dont il faut tenir compte en recherche par observation est le biais de sélection, où les sujets d'un échantillon ne sont pas représentatifs de la population. On peut utiliser un échantillon aléatoire, par exemple tous les patients qui vont subir une anesthésie. Cependant, trop souvent dans la littérature, le chercheur n'a pas assemblé un échantillon véritablement aléatoire, mais inclut les patients qui lui sont disponibles. Ces cas sont choisis parce qu'ils conviennent à l'évaluateur et ceci constitue un échantillon de convenance. Les postulats que l'on dit vouloir respecter en choisissant un échantillon de 
convenance sont que les « cas » choisis sont représentatifs de tous les patients avec la maladie choisie et que les contrôles sont des témoins des personnes sans cette maladie. Ces postulats ne sont pas toujours justes et produisent des résultats biaisés.

Qui devrait appartenir au groupe contrôle du chercheur? 11 y a plusieurs stratégies qui pourraient présider au choix des contrôles. Le chercheur pourrait étudier un échantillon aléatoire de patients hospitalisés qui n'ont pas la maladie évaluée, et les apparier par groupes d'âge (e.g., cinq ans) et de lieu de résidence au groupe cible. Une meilleure approche même, dans certaines circonstances, serait une "nomination » par un patient du groupe cible. Pour ce faire, le chercheur demande à un patient de ce groupe-cible de nommer une connaissance personnelle d'à peu près le même âge qui pourrait servir de contrôle. Puisque les gens tendent à se regrouper socialement avec d'autres personnes du même profil socio-démographique, le contrôle suggéré sera semblable à la personne du groupe cible. Des facteurs supplémentaires tels que la diète et le tabac pourront aussi avoir été définis par le chercheur puisque ceux-ci peuvent influencer l'événement-cible étudié. Puisque le choix de "contrôles" représentatifs est plus coûteux et demande plus d'énergie, nous pouvons comprendre pourquoi un chercheur est facilement tenté d'utiliser un échantillon de convenance.

\section{Pourquoi les anesthésistes devraient-ils prendre connaissance de l'épidémiologie?}

I La spécialité semble sous l'emprise des méthodes traditionnelles, telles l'utilisation des rapports de cas, des séries de cas, des anecdotes, et d'échange d'expérience individuelle. $11 \mathrm{y}$ a plusieurs autres plans de recherche qui pourraient être utiles pour l'identification des problèmes de pratique clinique.

2 Les résultats des travaux chez les animaux ne peuvent pas toujours être transférés directement chez l'humain (ex.: dioxine, cigarettes). Les études pertinentes doivent être faites chez l'homme pour connaître définitivement les effets d'une substance ou d'une intervention, mais une étude contrôlée randomisée n'est pas toujours réalisable ou peut présenter des problèmes d'éthique.

3 A cause des considération financières, du contrôle des coûts et des ressources, il y a un besoin croissant de réaliser des études d'efficacité, d'impact et d'efficience pour les nouvelles technologies et substances. Les études contrôlées ne sont pas toujours réalisables et des alternatives peuvent révéler certaines réponses. L'essort de la préoccupation du public pour les dépenses crée un plus grand besoin de démontrer qu'une approche clinique particulière n'est pas seulement d'une efficacité réelle pour surmonter le problème qui se pose mais qu'elle est la plus efficiente en termes de coûts.
L'épidémiologie peut être utile pour mener à bien ces évaluations.

Certaines des questions où l'épidémiologie aidera l'anesthésiste à répondre à certaines questions sont énumérées dans la tableau I. Celle-ci inclut des questions à propos du diagnostic, de la fréquence d'un problème, des risques, du pronostic, du traitement, de la prévention et des relations cause-effet.

Pour l'étude des événements indésirables en anesthésie, des méthodes d'observation ont démontré leur faisabilité, leur fiabilité et leur validité. Les types principaux d'événements étudiés en épidémiologie et les exemples d'études menées au Manitoba sont montrés dans la tableau II.

Il y a un courant actuel dans la recherche sur les événements-cibles (outcomes) qui s'intéresse de plus en plus aux bases de données. Les bases de données peuvent être définies comme le recueil systématique de données utilisées souvent pour des raisons autres que la recherche. Au Centre des Sciences de la Santé de Winnipeg, le département d'anesthésie a un programme de suivi des patients depuis 1974, qui a compilé des informations à propos des patients, de la technique anesthésique et des médicaments utilisés, et des événements indésirables survenus pendant la période péri-opératoire. Les données ont été recueillies autant par des anesthésistes que par une infirmière du département d'anesthésie assignée à cette collecte. Donc pour chaque anesthésie, il y a une fiche informatisée de cet épisode. Il est vraisemblable que nous continuerons de voir plus d'hôpitaux et départements d'anesthésie recueillir ces bases de données.

Quels sont les avantages des bases de données?

Les bases de données sont relativement faciles à utiliser et relativement peu coûteuses à développer et à entretenir. On peut les utiliser pour répondre à un nombre de questions différentes plutôt qu'à la question unique d'une approche expérimentale. Elles peuvent aussi être utilisées pour avoir un premier aperçu de problèmes définis, ce qui nous permet de savoir s'il vaut la peine d'entreprendre une étude contrôlée randomisée. Si une telle étude est contraire à l'éthique ou non réalisable, les bases de données avec leur grand nombres de cas, peuvent aider à répondre à des questions de recherche. Les bases de données seront souvent reliées à d'autres bases de données pour obtenir des informations additionnelles. Les bases de données seront utiles pour la surveillance des événements indésirables, l'examen de l'allocation des ressources, l'administration et autres fins.

Quels sont les inconvénients des bases de données? Les bases de données sont une forme d'étude par observation et peuvent être sujettes à un certain nombre de biais. La recherche basée sur des données, puisqu'elle est d'obser- 
TABLEAU I* Questions que l'épidémiologie aidera à répondre

\begin{tabular}{|c|c|}
\hline & Exemple tiré de l'anesthésie \\
\hline $\begin{array}{l}\text { NORMALITÉ/NON-MORMALITE: Est-ce qu'une personne est malade ou en } \\
\text { santé? }\end{array}$ & $\begin{array}{l}\text { Quelle sera l'évolution normale de personnes qui reçoivent de } \\
\text { l'anesthésie? }\end{array}$ \\
\hline $\begin{array}{l}\text { DIAGNOSTIC: Quel est la précision des tests ou des stratégies } \\
\text { diagnostiques utilisces pour détecter une maladie? }\end{array}$ & $\begin{array}{l}\text { Comment pourrez-vous prédire quels patients auront un épisode } \\
\text { d'hyperthermie maligne et lesquels n'en auront pas? }\end{array}$ \\
\hline $\begin{array}{l}\text { FRÉQUENCE: Quel est l'incidence d'une maladic? Quelles sont ses } \\
\text { changements dans le temps? }\end{array}$ & $\begin{array}{l}\text { Quel sera le taux d'infarctus du moycarde en post-opératoirc? Dans le } \\
\text { temps? }\end{array}$ \\
\hline $\begin{array}{l}\text { RISQUE: Quels facteurs sont associés avec une augmentation de } \\
\text { probabilité d'apparition d'une maladie? }\end{array}$ & $\begin{array}{l}\text { Quel sera le pronostic à long terme pour les patients qui ont des déficits } \\
\text { neurologiques post-opératoirc? }\end{array}$ \\
\hline PRONOSTIC: Quelles sont les conséquences d'avoir une maladie? & $\begin{array}{l}\text { Est-ce que l'utilisation des oxymètres pulsatils éliminera les épisodes } \\
\text { hypoxiques? }\end{array}$ \\
\hline $\begin{array}{l}\text { TRAITEMENT: Comment le traitement modifierat-il l'évolution d'une } \\
\text { maladie? Devrions-nous remplacer un vieux traitement par un nouveau? }\end{array}$ & Devrions-nous plutôt utiliser l'isoflurane? \\
\hline $\begin{array}{l}\text { Prévention: Est-ce que des interventions chez des personnes sans une } \\
\text { maladie vont leur permettre de prévenir l'apparition de celle-ci? }\end{array}$ & Est-ce que tous les patients devraient recevoir des anti-cmćtiques? \\
\hline $\begin{array}{l}\text { Est-ce que le dépistage précoce et le traitement vont modifier l'évolution } \\
\text { d'une maladie? }\end{array}$ & $\begin{array}{l}\text { Est-ce que cela fera une différence? Est-ce que cela nuira à certains } \\
\text { patients? }\end{array}$ \\
\hline CAUSE-EFFET: Quelles conditions peuvent amener une maladie? & $\begin{array}{l}\text { Est-ce que l'halothane est responsable de nécrose hépatique post- } \\
\text { općratoire? }\end{array}$ \\
\hline
\end{tabular}

*Modifié de Flctcher, Fletcher et Wagner. Clinical Epidemiology: the essentials.

TABLEAU II* Items d'intérêt en santé

\begin{tabular}{|c|c|}
\hline & Exemple en anesthésie \\
\hline $\begin{array}{l}\text { DÉcĖs: événement universel dont les moments d'apparition constituent } \\
\text { le centre d'intérêt. }\end{array}$ & $\begin{array}{l}\text { Quel est le taux de mortalité péri-opératoire relié à l'anesthésie (en } \\
\text { comparaison avec la chirurgic)? }\end{array}$ \\
\hline $\begin{array}{l}\text { MALADIE: combinaison de symptôme, signes physiques et résultats de } \\
\text { laboratoire. }\end{array}$ & Qucl est la morbidité reliéc à l'anesthésic? \\
\hline $\begin{array}{l}\text { INCAPACirÉ: l'état fonctionnel des patients en terme de capacité à vivre } \\
\text { leur vie quotidienne à la maison, au travail ou dans les périodes de loisirs. }\end{array}$ & $\begin{array}{l}\text { Pour les patients ambulatoires, est-ce que le choix de l'agent } \\
\text { anesthésique va retarder le retour au travail? }\end{array}$ \\
\hline $\begin{array}{l}\text { INCOMFORT: symptôme déplaisant, tel la doulcur, la nausée, les vertiges, } \\
\text { le tinnitus ou la fatigue. }\end{array}$ & $\begin{array}{l}\text { Qucls sont les fréquences d'apparition de nausées ct vomissements } \\
\text { post-opératoirc, de céphalée. de maux de dos, etc.? }\end{array}$ \\
\hline $\begin{array}{l}\text { INSATISFACTION: état mental ou émotif, tel que l'agitation, la tristesse } \\
\text { ou la colère. }\end{array}$ & $\begin{array}{l}\text { Est-ce que le nombre de poursuites médico-légales en anesthésie } \\
\text { augmente? }\end{array}$ \\
\hline DOLlaRs: quel est l'impact financier de la maladie et de son traitement? & Est-ce que le coût des nouveaux monitcurs est justifié? \\
\hline
\end{tabular}

*Modifié de Fletcher, Fletcher et Wagner.

vation, implique habituellement " de la génération d'hypothèse" plutôt que de la vérification d'hypothèse. Les bases de données peuvent répondre uniquement aux questions pertinentes aux variables recueillies. Si de nouveaux problèmes sont soulevés, ceux-ci peuvent ne pas avoir été inclus dans la collecte de données. L'information dans une base de données sera variable dans sa fiabilité et sa validité, et ceux qui utilisent de telles données doivent être conscients de leurs limites.

La réalité de la pratique en clinique nous montre que les patients ne se comportent pas toujours comme les études physiologiques et biochimiques nous le suggéreraient. II est beaucoup plus difficile de définir la vérité en médecine clinique et d'y porter un jugement. Quelques-unes des méthodes de l'épidémiologie peuvent être utiles aux praticiens. Il serait bénéfique d'établir de nouveaux liens entre les spécialités de l'anesthésie et de l'épidémiologie, ce qui servirait leurs intérêts mutuels.

\section{Bibliographie}

(Voir page Sxlviii) 